\title{
Urinary excretion of L-carnitine, acetyl-L-carnitine, propionyl- L-carnitine and their antioxidant activities after single dose administration of L-carnitine in healthy subjects
}

\author{
Yu Cao ${ }^{1,2}$, Chuan-ji Hao ${ }^{2}$, Chen-jing Wang ${ }^{2}$, Peng-li Li ${ }^{1}$, Le-xin Wang ${ }^{3}$ Hua-shi Guan ${ }^{1, *}$, \\ Huan-ting $\mathbf{L i}^{2}$
}

\begin{abstract}
${ }^{1}$ Key Laboratory of Marine Drugs, Ministry of Education, School of Medicine and Pharmacy, Ocean University of China, Qingdao, China, ${ }^{2}$ The Affiliated Hospital of Medical College Qingdao University, Qingdao, China, ${ }^{3}$ School of Biomedical Sciences, Charles Sturt University, Wagga Wagga, Australia
\end{abstract}

\begin{abstract}
The urine excretion of L-carnitine (LC), acetyl-L-carnitine (ALC) and propionyl-Lcarnitine (PLC) and their relations with the antioxidant activities are presently unknown. Liquid L-carnitine $(2.0 \mathrm{~g})$ was administered orally as a single dose in 12 healthy subjects. Urine concentrations of LC, ALC and PLC were detected by HPLC. Superoxide dismutase (SOD), total antioxidative capacity (T-AOC), malondialdehyde (MDA) and nitrogen monoxidum (NO) activities were measured by spectrophotometric methods. The $0 \sim 2 \mathrm{~h}, 2 \sim 4 \mathrm{~h}, 4 \sim 8 \mathrm{~h}, 8 \sim 12 \mathrm{~h}, 12 \sim 24 \mathrm{~h}$ excretion of LC was $53.13 \pm 31.36 \mu \mathrm{mol}, 166.93 \pm 76.87 \mu \mathrm{mol}$, $219.92 \pm 76.30 \mu \mathrm{mol}, 100.48 \pm 23.89 \mu \mathrm{mol}, 72.07 \pm 25.77 \mu \mathrm{mol}$, respectively. The excretion of ALC was $29.70 \pm 14.43 \mu \mathrm{mol}, 80.59 \pm 32.70 \mu \mathrm{mol}, 109.85 \pm 49.21 \mu \mathrm{mol}, 58.65 \pm 18.55 \mu \mathrm{mol}$, and $80.43 \pm 35.44 \mu \mathrm{mol}$, respectively. The urine concentration of PLC was $6.63 \pm 4.50 \mu \mathrm{mol}, 15.33 \pm 12.59 \mu \mathrm{mol}, 15.46 \pm 6.26 \mu \mathrm{mol}$, $13.41 \pm 11.66 \mu \mathrm{mol}$ and $9.67 \pm 7.92 \mu \mathrm{mol}$, respectively. The accumulated excretion rate of LC was $6.1 \%$ within $24 \mathrm{~h}$ after its administration. There was also an increase in urine concentrations of SOD and T-AOC, and a decrease in NO and MDA. A positive correlation was found between urine concentrations of LC and SOD $(\mathrm{r}=0.8277)$ or T-AOC $(\mathrm{r}=0.9547)$, and a negative correlation was found between urine LC excretions and NO $(r=-0.8575)$ or MDA $(r=0.7085)$. In conclusion, a single oral LC administration let to a gradual increase in urine L-carnitine excretion which was associated with an increase in urine antioxidant enzymes and the total antioxidant capacities. These data may be useful in designing therapeutic regimens of $\mathrm{LC}$ or its analogues in the future.
\end{abstract}

Uniterms: L-carnitine/antioxidant activity. Acetyl-L-carnitine/antioxidant activity. Propionyl-Lcarnitine/ antioxidant activity. Antioxidants. Urine excretion/analysis.

A excreção urinária de L-carnitina (LC), acetil-L-carnitina (ALC) e propionil-L-carnitine (PLC) e as suas relações com as atividades antioxidantes são presentemente desconhecidos. Líquido de L-carnitina $(2,0 \mathrm{~g})$ foi administrada por via oral como uma dose única em 12 indivíduos saudáveis. As concentrações urinárias de LC, PLC e ALC foram detectados por HPLC. Atividades superóxido dismutase (SOD), a capacidade antioxidante total (T-AOC), malondialdeído (MDA) e óxido nítrico (NO) foram medidas por métodos espectrofotométricos. O $0 \sim 2 \mathrm{~h}, 2 \sim 4 \mathrm{~h}, 4 \sim 8 \mathrm{~h}, 8 \sim 12 \mathrm{~h}, 12 \sim 24 \mathrm{~h}$ excreção de LC foi 53,13 $\pm 31.36 \mu \mathrm{mol}, 166,93 \pm 76.87 \mu \mathrm{mol}, 219,92 \pm 76.30 \mu \mathrm{mol}, 100,48 \pm 23.89 \mu \mathrm{mol}$, $72,07 \pm 25.77 \mu \mathrm{mol}$, respectivamente. A excreção de ALC foi 29,70 $\pm 14.43 \mu \mathrm{mol}, 80,59 \pm 32.70 \mu \mathrm{mol}$, $109,85 \pm 49.21 \mu \mathrm{mol}, 58,65 \pm 18.55 \mu \mathrm{mol}$, e $80,43 \pm 35.44 \mu \mathrm{mol}$, respectivamente. A concentração de urina de PLC foi $6,63 \pm 4.50 \mu \mathrm{mol}, 15,33 \pm 12.59 \mu \mathrm{mol}, 15,46 \pm 6.26 \mu \mathrm{mol}, 13,41 \pm 11.66 \mu \mathrm{mol} \mathrm{e}$ $9,67 \pm 7.92 \mu \mathrm{mol}$, respectivamente. A taxa de excreção acumulada de LC foi de $6,1 \% 24$ horas após sua administração. Houve também um aumento nas concentrações de urina de SOD e T-COA e diminuição de NO e de MDA. Correlação positiva foi encontrada entre as concentrações de urina de LC e SOD $(\mathrm{r}=0,8277)$ ou T-AOC $(\mathrm{r}=0,9547)$ e correlação negativa entre a excreção de LC e NO $(\mathrm{r}=-0,8575)$ ou MDA $(r=0,7085)$. Em conclusão, a administração oral única de LC leva ao aumento gradual na excreção urinária de L-carnitina, que foi associada com o aumento das enzimas antioxidantes na urina

\footnotetext{
*Correspondence: Hua-shi Guan. School of Medicine and Pharmacy, Ocean
}

University of China, Qingdao, PR China. E-mail: ??????? 
e as capacidades antioxidantes totais. Estes dados podem ser úteis no futuro para o planejamento de esquemas terapêuticos de LC ou os seus análogos, no futuro.

Unitermos: L-carnitina/atividade antioxidante. Acetil-L-carnitina/atividade antioxidante. Antioxidantes. Urina/excreção/análise.

\section{INTRODUCTION}

L-carnitine (3-hydroxy-4- $N$-trimethylammonium butyrate, LC) is an endogenous compound which has several physiological functions. LC is involved in the transfer of long-chain fatty acids across the inner matrix membrane of mitochondria (Mancinelli et al., 2007). It also regulates acetyl storage and transfer in mitochondria, cells, and between organs, and the transport of potentially toxic, activated acids out of mitochondria (Bellinghieri et al., 2003). LC is believed to be important for acting as an osmo protectant in organs such as the kidney, and as a general cell membrane stabilizer (Lahjouji et al., 2004; Biolo et al., 2008). LC homeostasis is maintained by a modest biosynthesis in the liver and kidney, absorption from dietary sources (eg, meat and dairy products), and efficient renal tubular reabsorption from glomerular filtrate (Rebouche, Seim 1998). Short-chain carnitine esters, including acetylLcarnitine (ALC) and propionyl-L-carnitine (PLC), are produced by esterification of the hydroxyl group of LC. LC, ALC and PLC form components of the endogenous carnitine pools in humans and experimental animals (Mancinelli et al., 2000). There is a reciprocal transformation among the three carnitine analogues (LC, ALC and PLC) (Cao et al., 2009). Acetylation of L-carnitine and the transformation to ALC or PLC can take place during the absorption process (Gross, Henderson, 1984; Gudjonsson et al. 1985).

LC is administered clinically for the treatment of primary and secondary carnitine deficiency syndromes. Available biochemical and clinical information provides a strong rationale for carnitine supplementation to patients on hemodialysis (Guarnieri et al., 2007). Bioavailability of dietary LC in individuals adapted to low-carnitine is between $54 \%$ to $72 \%$ (Rebouche, Chenard, 1991). However, the bioavailability of L-carnitine from oral supplements was lower than dietary LC, ranging from $14 \%-18 \%$ of the total dose (Rebouche, 2004). ALC supplementation has been reported to reduce the progression of Alzheimer's disease (Gavrilova et al., 2011; Pettegrew, McClure 2002). Patients with intermittent claudication exhibited improved walking capacity after the administration of PLC (Brevetti et al., 1995).

Apart from the physiological roles in intermedi- ary metabolism, LC has also been found to possess antioxidant properties, such as prevention of DNA damages and increase of non-enzymatic and enzymatic antioxidant levels (Ribas et al., 2012; Derin et al., 2004). $\mathrm{LC}$ also raises the activities of blood antioxidant enzymes and total antioxidant capacity in a concentration-dependent manner (Cao et al., 2011). However, there has been limited information about the relationships between the urine concentrations of LC and and anti-oxidation in in healthy humans. The aim of this study was to investigate the urine concentration of LC, ALC and PLC after a single oral administration of L-carnitine solution in healthy volunteers, and to evaluate their urine antioxidant status through the measurement of superoxide dismutase (SOD), total antioxidative capacity (T-AOC), nitrogen monoxidum (NO), and malondialdehyde (MDA) activities in the urine.

\section{MATERIALS AND METHODS}

\section{Drugs, reagents and apparatus}

Standard preparations of L-carnitine (purity 99\%, batch No. 060708, $10 \mathrm{ml}: 1 \mathrm{~g}$ ) were obtained from Northeast Pharmaceutical Group Co., China. 1-Ethyl3-(3-dimethyllaminopropyl) carbodiimide hydrochloride (EDC-HCL) and 1-aminoanthracen (1-AA) were supplied by Sigma. Acetonitrile (HPLC grade reagent) was purchased from Honeywell international INC. Other reagents (hydrochloric acid, acetone, ammonium acetate, aether, glacial acetic acid, chloroform) were of analytical grade.

\section{Study participants}

This study was approved by the Institutional Review Board of Qingdao University. Informed written consent was obtained from all participants. Healthy volunteers were invited from the staff working at the hospital clinics and those who attended the clinics for annual health check-ups. All subjects were free from pulmonary, neurologic, hematologic and gastrointestinal diseases. None of the participants were past or current smokers. A thorough physical examination was performed, and the 
following laboratory tests were conducted: blood cell counts, biochemistry profile, liver and renal function tests and electrocardiogram. The volunteers were not permitted to consume alcohol for $72 \mathrm{~h}$ before or during the study, and were asked to abstain from any medications for at least 1 week before and during the study. All subjects were prescribed a similar diet commencing two weeks before the study. In the prescribed diet there were green vegetables, rice, $50 \mathrm{~g}$ /day of cooked chicken meat, but no milk, other forms of meat or diary product such as cheeses.

\section{Study design}

A single dose of LC ( $2.0 \mathrm{~g}$ in $200 \mathrm{~mL}$ warm water) was administered orally to all participants. The Urine was collected just before $(0 \mathrm{~h})$ and at $0 \sim 2 \mathrm{~h}, 2 \sim 4 \mathrm{~h}, 4 \sim 8 \mathrm{~h}$, $8 \sim 12 \mathrm{~h}$, and 12 24 h after the oral administration of LC. The urine volume at each time point was recorded. Five $\mathrm{ml}$ of the urine was transferred into a polypropylene tube and kept at $-20{ }^{\circ} \mathrm{C}$ for analysis.

\section{Chromatographic conditions and extraction procedure}

The analytes were precolumn derivatived with 1aminoanthracene (1-AA). The fluorescent derivatives were separated on a Hypersil $\mathrm{C}_{18}$ column, and the mobile phase consisted of acetonitrile- 0.1 mol.L $\mathrm{L}^{-1}$ ammonium acetate (34:66), the flow rate was $1.0 \mathrm{~mL} \cdot \mathrm{min}^{-1}$. The derivatives were monitored with a fluorimetric detector set at $248 \mathrm{~nm}$ excitation wavelength and $418 \mathrm{~nm}$ emission wavelength. We have previously reported the extraction procedure and validation of the methodologies (Cao et al., 2009, 2011).

\section{Determination of urine excretion and accumulated excretion rate}

The urine excretion was a summation of excretion through multiplying the concentration and volume in $0 \sim 2 \mathrm{~h}, 2 \sim 4 \mathrm{~h}, 4 \sim 8 \mathrm{~h}, 8 \sim 12 \mathrm{~h}, 12 \sim 24 \mathrm{~h}$, respectively. The accumulated excretion rate of LC was calculated by dividing accumulated excretion of LC with the oral dose $(2.0 \mathrm{~g})$.

\section{Determination of antioxidant index}

The urine samples were subjected to the measurement of SOD, T-AOC, NO and MDA by spectrophotometric methods according to the procedures provided by the assay kits (purchased from Nanjing Jiancheng Bioengineering Institute, Nanjing, China).

\section{Statistical analysis}

Data are expressed as means \pm SD. SPSS15.1 software was used for data analysis. Numerical data were analyzed with one-way ANOVA. Categorical data were analyzed with Chi-square test. Pearson correlation was used to analyze the correlations between $\mathrm{LC}$ and the concentrations of SOD or T-AOC, NO or MDA. $P<0.05$ was considered statistically significant.

\section{RESULTS}

\section{Urine excretion of LC, ALC, PLC and accumulated excretion rate of $L C$}

The $0 \sim 2$ h, 2 4 h, 4 8 h, 8 12 h, 12 24 h urine excretion of LC was $53.13 \pm 31.36 \mu \mathrm{mol}, 166.93 \pm 76.87 \mu \mathrm{mol}$, $219.92 \pm 76.30 \mu \mathrm{mol}, 100.48 \pm 23.89 \mu \mathrm{mol}$ and $72.07 \pm 25.77 \mu \mathrm{mol}$, respectively. The excretion of ALC was $29.70 \pm 14.43 \mu \mathrm{mol}, 80.59 \pm 32.70 \mu \mathrm{mol}$, $109.85 \pm 49.21 \mu \mathrm{mol}, 58.65 \pm 18.55 \mu \mathrm{mol}$, and $80.43 \pm 35.44 \mu \mathrm{mol}$, respectively, and the urine excretion of PLC was $6.63 \pm 4.50 \mu \mathrm{mol}, 15.33 \pm 12.59 \mu \mathrm{mol}$, $15.46 \pm 6.26 \mu \mathrm{mol}, 13.41 \pm 11.66 \mu \mathrm{mol}$, and $9.67 \pm 7.92 \mu \mathrm{mol}$, respectively (Figure 1). The accumulated urine excretion rate of LC was $6.1 \%$ within $24 \mathrm{~h}$ after its administration.

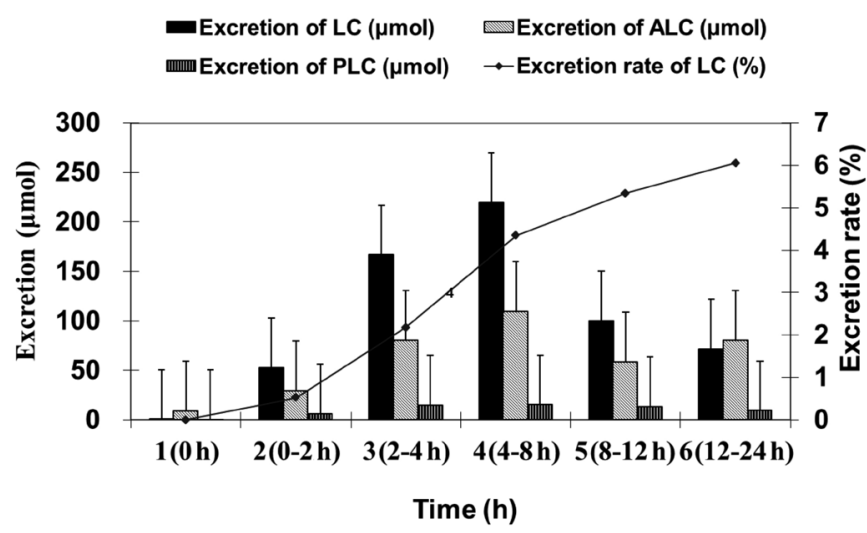

FIGURE 1 - The urinary excretion of LC, ALC, PLC and the urinary excretion rate of $\mathrm{LC}$ after single oral administration.

\section{Urinary antioxidant status}

As shown in Table I, after single oral administration of LC, the excretion of LC increased gradually from $0 \sim 2 \mathrm{~h}$ to $4 \sim 8 \mathrm{~h}$, and reached the peak at $4 \sim 8 \mathrm{~h}$. The antioxidant index of SOD and T-AOC had the same transmutation as the excretion, however NO and MDA had a conversely changing tendency. The mean concentrations of SOD and T-AOC in $2 \sim 4 \mathrm{~h}, 4 \sim 8 \mathrm{~h}$ were higher than in $0 \sim 2 \mathrm{~h}(P$ 
TABLE I - The urine excretion of L-carnitine and the antioxidative parameters

\begin{tabular}{lccccc}
\hline Time $(\mathrm{h})$ & Excretion $(\mu \mathrm{mol})$ & SOD U $\left(\mathrm{mL}^{-1}\right)$ & T-AOC $\left(\mathrm{U} \mathrm{mL}^{-1}\right)$ & $\left.\mathrm{NO}(\mu \mathrm{mol} \mathrm{L})^{-1}\right)$ & $\mathrm{MDA}\left(\mu \mathrm{mol} \mathrm{mL}^{-1}\right)$ \\
\hline 0 & $0.94 \pm 0.82$ & $17.49 \pm 5.69$ & $28.67 \pm 7.08$ & $3.69 \pm 1.98$ & $3.05 \pm 1.99$ \\
$0 \sim 2$ & $53.13 \pm 31.36$ & $22.53 \pm 10.01$ & $40.13 \pm 16.70$ & $2.12 \pm 0.68$ & $2.86 \pm 1.62$ \\
$2 \sim 4$ & $166.93 \pm 76.87 * *$ & $39.70 \pm 10.46^{*}$ & $64.92 \pm 22.86^{*}$ & $0.40 \pm 0.10^{*}$ & $0.16 \pm 0.10^{*}$ \\
$4 \sim 8$ & $219.92 \pm 76.30^{* *}$ & $33.31 \pm 10.95^{*}$ & $64.12 \pm 30.77^{*}$ & $0.72 \pm 0.39^{*}$ & $0.65 \pm 0.42^{*}$ \\
$8 \sim 12$ & $100.48 \pm 23.89^{* *}$ & $26.19 \pm 12.18$ & $46.90 \pm 22.84$ & $1.05 \pm 0.79 *$ & $0.67 \pm 0.62^{*}$ \\
$12 \sim 24$ & $72.07 \pm 25.77^{*}$ & $24.08 \pm 8.37$ & $43.44 \pm 15.28$ & $1.70 \pm 0.88$ & $1.26 \pm 1.09$ \\
\hline
\end{tabular}

SOD, superoxide dismutase activity; T-AOC, total antioxidative capacity; NO, nitrogen monoxidum; MDA, malondialdehyde. $* P<0.05$ and ${ }^{*} P<0.01$, compared with $0 \sim 2 \mathrm{~h}$.

$<0.05)$, however the mean concentrations of $\mathrm{NO}$ and $\mathrm{MDA}$ in $2 \sim 4 \mathrm{~h}, 4 \sim 8 \mathrm{~h}$ and $8 \sim 12 \mathrm{~h}$ were lower than in $0 \sim 2 \mathrm{~h}(P$ $<0.05)$.

\section{Correlation analysis}

A positive correlation was found between excretion of LC and urine concentrations of SOD $(r=0.8277)$ or T-AOC $(r=0.9547)$. A negative correlation was found between LC excretion and NO $(r=-0.8575)$ or MDA $(r=-0.7085)$.

\section{DISCUSSION}

The present study found that urine excretion of LC, ALC, and PLC started within one hour and reached its peak between 4-8 $\mathrm{h}$ after a single oral administration in healthy subjects. This study also demonstrated a gradual increase in the urine antioxidant index of SOD and T-AOC within the first $8 \mathrm{~h}$ of LC administration. Furthermore, a positive correlation was found between urine LC excretion and urine concentrations of SOD or T-AOC.

In 1991, Rebouche (1991) published a pivotal paper that provided a quantitative estimation of the fate of an oral tracer dose of $\mathrm{L}-[$ methyl-3H]-carnitine in five men who were receiving a high-carnitine diet and L-carnitine supplementation. It was found that the absorption of oral $\mathrm{L}-[3 \mathrm{H}]$-carnitine was slow and incomplete, with $\mathrm{t}_{\max }$ values of $2-4.5$ hours. This suggests a prolonged retention of that fraction of the dose that had been incorporated into the body's carnitine pool. In their study, only $6.3 \%$ of the oral LC dose was recovered unchanged in the urine, with a further 34\% recovered in urine as metabolites, mostly $[3 \mathrm{H}]$-trimethylamine- $N$-oxide (Rebouche, 1991). About $22 \%$ of the dose was recovered in feces, mostly as labeled $\gamma$-butyrobetaine (Rebouche, 1991). In our study, after a single dose of LC, the urine excretion of LC increased gradually from $0 \sim 2 \mathrm{~h}$ to $4 \sim 8 \mathrm{~h}$, and reached the peak at
$4 \sim 8 \mathrm{~h}$. The excretion rate of L-carnitine was only $6.1 \%$, which was consistent with Rebouche's report (Rebouche, 1991). The excretion of ALC and PLC also increased and reached the peak within $8 \mathrm{~h}$ following LC administration, which suggests that acetylation of LC and the transformation to ALC or PLC can take place in vivo. One notable variation was that the excretion of ALC between 12-24 h was greater than that between $8-12 \mathrm{~h}(80.4 \mathrm{vs} 58.7 \mu \mathrm{mol})$. The reason for this is unclear, but whether there is a second phase of urinary ALC excretion $12 \mathrm{~h}$ after LC administration requires further investigation.

In kidneys, LC decreased the severity of renal cortical proximal tubular necrosis and improved renal function in rats with gentamicin-induced or doxorubicin-induced renal injury (Boonsanit et al., 2006; Kopple et al., 2002). LC reversed the increases in blood BUN and creatinine following the doxorubicin or gentamicin caused renal injuries. LC has been shown to reduce the severity of glycerol-induced myoglobinuric kidney damages, indicating that LC may be a beneficial agent in the prevention and treatment of glycerol-induced myoglobinuric acute renal failure (Ustundag et al., 2009). The mechanisms of the renal protective effect of LC are not entirely clear. In previous studies, LC has been shown to have antioxidant effects against oxidative damage in different organs or tissues, including the kidney (Aydogdu et al., 2006; Chang et al., 2002). It has been demonstrated that LC administration inhibits both serum and kidney tissue MDA formation in response to renal ischaemia-reperfusion injury (Ergün et al., 2001). Carnitine supplementation has been found to enhance the activities of antioxidant enzymes, such as SOD, CAT and GPx, and decrease the MDA concentration in kidney tissues of 24-month-old rats (Kalaiselvi, Panneerselvam, 1998). The direct antioxidant effects of LC might contribute to attenuation of oxidative stress in kidney tissues (Sener et al., 2004). Antioxidant effects of carnitine were also shown in vitro studies, and in patients on hemodialysis (Guarnieri et al., 2007; Pertosa et al., 2005). 
These effects could in turn reduce oxidative stress-induced inflammation and insulin resistance (Evans et al., 2003). We have also previously reported that aadministration of liquid LC could raise the activities of plasma antioxidant enzymes and total antioxidant capacity in a concentrationdependent manner in healthy human volunteers (Cao et al., 2011). In the present study, the transmutation of urine SOD, T-AOC, NO, and MDA provides further evidence to confirm that LC could increase the antioxidant activities in healthy subjects.

There have been some studies to compare the effect of LC with other antioxidant biomolecules. In hypoxiainduced lipid peroxidation in the brain during postnatal ontogenesis, the protective effect of LC is comparable with the effect of tocopherol, well-known reactive species scavenger (Rauchová et al., 2012). In the obstructed kidney of rats subjected to 24-hr of unilateral ureteral obstruction (UUO), LC reduced oxidative stress and suppressed energy metabolism, while $\alpha$-tocopherol only prevented redox imbalance (Moosavi SM et al., 2011). The effect of LC on superoxide anion radical scavenging and hydrogen peroxide scavenging seems comparable with alpha-tocopherol and trolox (Gülçin, 2006). L-carnitine seems to have more protective effects than selenium on the electromagnetic radiation-induced blood toxicity by inhibiting free radical supporting antioxidant redox system (Gumral et al., 2009).

In this study, there was a moderate increase in urinary SOD within 2-8 hr of LC administration. The reasons for this SOD increase are unclear. SOD is a large molecule which is usually reabsorbed in the kidney and urine SOD should be negligible in healthy subjects. Whether LC increased kidney injury leading to higher SOD releaser requires further investigation.

In summary, this study in healthy Chinese subjects has demonstrated that following oral administration of $\mathrm{LC}$, there was a gradual increase in the urine excretion of L-carnitine, ALC and PLC, with a peaking excretion occurring between 4 and $8 \mathrm{~h}$ after the drug administration. This study also showed that there was an increase in the antioxidant activities in the urine after LC administration. The antioxidant activities were closely correlated with the urine LC excretion. These data may be useful in designing therapeutic regimens of L-carnitine or its analogues in the future.

\section{ACKNOWLEDGMENTS}

This study was supported by a research grant from Chinese national key technology R\&D program and medical science technology program of Shandong Province.

\section{CONFLICT OF INTEREST}

None to declare.

\section{REFERENCES}

AYDOGDU, N.; ATMACA, G.; YALCIN, O.; TASKIRAN, R.; TASTEKIN, E.; KAYMAK, K. Protective effects of L-carnitine on myoglobinuric acute renal failure in rats. Clin. Exp. Pharmacol. Physiol., v.33, p.119-24, 2006.

BELLINGHIERI, G.; SANTORO, D.; CALVANI, M.; MALLAMACE, A.; SAVICA, V. Carnitine and hemodialysis. Am. J. Kidney. Dis., v.41, suppl.1, p.S116-S122, 2003.

BIOLO, G.; STULLE, M.; BIANCO, F.; MENGOZZI, G.; BARAZZONI, R.; VASILE, A.; PANZETTA, G.; GUARNIERI, G. Insulin action on glucose and protein metabolism during L-carnitine supplementation in maintenance haemodialysis patients. Nephrol. Dial. Transplant., v.23, p.991-997, 2008.

B O ONSANIT, D.; KANCHANAPANGKA, S.; BURANAKARL, C. L-carnitine ameliorates doxorubicininduced nephrotic syndrome in rats. Nephrology (Carlton), v.11, p.313-320, 2006.

BREVETTI, G.; PERNA, S.; SABBÁ, C.; MARTONE, V.D.; CONDORELLI, M. Propionyl-L-carnitine in intermittent claudication: double-blind, placebo-controlled, dose titration, multicenter study. J. Am. Coll. Cardiol., v.26, p.1411-1416, 1995.

CAO, Y.; WANG, Y.X.; LIU, C.J.; WANG, L.X.; HAN, Z.W.; WANG ,C.B. Comparison of pharmacokinetics of L-carnitine, acetyl-L-carnitine and propionyl-L-carnitine after single oral administration of L-carnitine in healthy volunteers. Clin. Invest. Med., v.32, p.E13-E19, 2009.

CAO, Y.; QU, H.J.; LI, P.; WANG, C.B.; WANG, L.X.; HAN, Z.W. Single dose administration of L-carnitine improves antioxidant activities in healthy subjects. Tohoku J. Exp. Med., v.224, p.209-13, 2011.

CHANG, B.; NISHIKAWA, M.; SATO, E.; UTSUMI, K.; INOUE, M. L-Carnitine inhibits cisplatin-induced injury of the kidney and small intestine. Arch. Biochem. Biophys., v.405, p.55-64, 2002. 
DERIN, N.; IZGUT-UYSAL, V.N.; A GAC,A.; ALICIGUZEL, Y.; DEMIR, N. L-carnitine protects gastric mucosa by decreasing ischemia-reperfusion induced lipid peroxidation. J. Physiol. Pharmacol., v.55, p.595-606, 2004.

ERGÜN, O.; ULMAN, C.; KILIÇALP, A.S.; ULMAN, I. Carnitine as a preventive agent in experimental renal ischemia-reperfusion injury. Urol. Res., v.29, p.186-189, 2001 .

EVANS, J.L.; GOLDFINE, I.D.; MADDUX, B.A.; GRODSKY, G.M. Are oxidative stress-activated signaling pathways mediators of insulin resistance and beta-cell dysfunction? Diabetes., v.52, p.1-8, 2003.

GAVRILOVA, S.I.; KALYN, I.B.; KOLYKHALOV, I.V.; ROSHCHINA, I.F.; SELEZNEVA, N.D. Acetyl-Lcarnitine (carnicetine) in the treatment of early stages of Alzheimer's disease and vascular dementia. Zh. Nevrol. Psikhiatr. Im. SS. Korsakova, v.111, p.16-22, 2011.

GROSS, C.J.; HENDERSON, L.M. Absorption of D- and L-carnitine by the intestine and kidney tubule in the rat. Biochim. Biophys. Acta., v.772, p.209-219, 1984.

GUARNIERI, G.; BIOLO, G.; VINCI, P.; MASSOLINO, B.; BARAZZONI, R. Advances in carnitine in chronic uremia. J. Ren. Nutr., v.17, p.23-29, 2007.

GUDJONSSON, H.; LI, B.U.; SHUG, A.L.; OLSEN, W.A. In vivo studies of intestinal carnitine absorption in rats. Gastroenterology, v.88, p.1880-1887, 1985.

KALAISELVI, T.; PANNEERSELVAM, C. Effect of L-carnitine on the status of lipid peroxidation and antioxidants in aging rats. J. Nutr. Biochem., v.9, p.575581,1998 .

GÜLÇIN I. Antioxidant and antiradical activities of L-carnitine. Life Sci., v.18, p.803-811, 2006.

GUMRAL, N.; NAZIROGLU, M.; KOYU, A.; ONGEL, K.; CELIK, O.; SAYGIN, M.; KAHRIMAN, M.; CALISKAN, S.; KAYAN, M.; GENCEL, O.; FLORESARCE, MF. Effects of selenium and l-carnitine on oxidative stress in blood of rat induced by $2.45-\mathrm{ghz}$ radiation from wireless devices. Biol. Trace Elem. Res., v.132, p.153-63, 2009.
KALAISELVI, T.; PANNEERSELVAM, C. Effect of 1-carnitine on the status of lipid peroxidation and antioxidants in aging rats. J. Nutr. Biochem., v.9, p.575$581,1998$.

KOPPLE, J.D.; DING, H.; LETOHA, A.; IVANYI, B.; QING, D.P.; DUX, L.; WANG, H.Y.; SONKODI, S. L-carnitine ameliorates gentamicin-induced renal injury in rats. Nephrol. Dial. Transplant., v.17, p.2122-2131, 2002.

LAHJOUJI, K.; ELIMRANI, I.; LAFOND, J.; LEDUC, L.; QURESHI, I.A.; MITCHELL, G.A. L-Carnitine transport in human placental brush-border membranes is mediated by the sodium-dependent organic cation transporter OCTN2. Am. J. Physiol. Cell. Physiol., v.287, p.C263-C239, 2004.

LONGO, A.; BRUNO, G.; CURTI, S.; MANCINELLI, A.; MIOTTO, G. Determination of L-carnitine, acetyl-Lcarnitine and propionyl-L-carnitine in human plasma by high-performance liquid chromatography after pre-column derivatization with 1-aminoanthracene. J. Chromatogr. B. Biomed. Appl., v.686, p.129-139, 1996.

MANCINELLI, A.; LONGO, A.; NATION, R.L.; EVANS, A.M. Disposition of L-carnitine and its short-chain esters, acetyl-L-carnitine and propionyl-L-carnitine, in the rat isolated perfused liver. Drug. Metab. Dispos., v.28, p.14011404, 2000.

MANCINELLI, A.; D'IDDIO, S.; BISONNI, R.; GRAZIANO, F.; LIPPE, P.; CALVANI M. Urinary excretion of L-carnitine and its short-chain acetyl-Lcarnitine in patients undergoing carboplatin treatment. Cancer Chemother. Pharmacol., v.60, p.19-26, 2007.

MOOSAVI, S.M.; ASHTIYANI, S.C.; HOSSEINKHANI, S. L-carnitine improves oxidative stress and suppressed energy metabolism but not renal dysfunction following release of acute unilateral ureteral obstruction in rat. Neurourol. Urodyn., v.30, p.480-487, 2011.

PERTOSA, G.; GRANDALIANO, G.; SIMONE, S.; SOCCIO, M.; SCHENA, F.P. Inflammation and carnitine in hemodialysis patients. J. Ren. Nutr., v.15, p.8-12, 2005.

PETTEGREW, J.W.; MCCLURE, R.J. Acetyl-1-carnitine as a possible therapy for Alzheimer's disease. Expert. Rev. Neurother., v.2, p.647-654, 2002. 
RAUCHOVÁ, H.; VOKURKOVÁ, M.; KOUDELOVÁ, J. Hypoxia-induced lipid peroxidation in the brain during postnatal ontogenesis. Physiol Res., v.61, suppl.1, p.S89-S101, 2012.

REBOUCHE, C.J.; CHENARD, C.A. Metabolic fate of dietary carnitine in human adults: identification and quantification of urinary and fecal metabolites. J. Nutr., v.121, p.539-546, 1991.

REBOUCHE, C.J. Quantitative estimation of absorption and degradation of a carnitine supplement by human adults. Metabolism, v.40, p.1305-1310, 1991.

REBOUCHE, C.J.; SEIM, H. Carnitine metabolism and its regulation in microorganisms and mammals. Annu. Rev. Nutr., v.18, p.39-61, 1998.

REBOUCHE, C.J. Kinetics, pharmacokinetics, and regulation of L-carnitine and acetyl-L-carnitine metabolism. Ann. N Y Acad. Sci., v.1033, p.30-41, 2004.
RIBAS, G.S.; BIANCINI, G.B.; MESCKA, C.; WAYHS, C.Y.; SITTA, A.; WAJNER, M.; VARGAS, C.R. Oxidative stress parameters in urine from patients with disorders of propionate metabolism: a beneficial effect of L-carnitine supplementation. Cell. Mol. Neurobiol., v.32, p.77-82, 2012.

SENER, G.; PASKALOĞLU, K.; SATIROGLU, H.; ALICAN, I.; KAÇMAZ, A.; SAKARCAN, A. L-carnitine ameliorates oxidative damage due to chronic renal failure in rats. J. Cardiovasc. Pharmacol., v.43, p.698-705, 2004.

USTUNDAG, S.; SEN, S.; YALCIN, O.; CIFTCI, S.; DEMIRKAN, B.; TURE, M. L-Carnitine ameliorates glycerol-induced myoglobinuric acute renal failure in rats. Ren. Fail., v.31, p.124-33, 2009.

Received for publication on $01^{\text {st }}$ October 2012 Accepted for publication on $03^{\text {rd }}$ January 2013 
